\title{
The relation between macroeconomic ambient and qualified healthcare workers: the case of the Republic of Serbia
}

\section{Однос макроекономског амбијента и квалификованих радника у здравственој заштити: случај Републике Србије}

\section{Mihailo Ćurčić *}

Assistant Professor / Research Associate, University of Defense, Social Sciences Department, Belgrade, Republic of Serbia, curcicmihailo@gmail.com

\section{Iva Matić}

Teaching Assistant, University for Business Studies, Faculty of Business and Financial Studies, Banja Luka, Bosnia and Herzegovina, mati.iva@yahoo.com

\section{Irena Milojević}

Teaching Assistant, School of Economic and Management Studies, Kragujevac, Republic of Serbia, i.miloje.bg@gmail.com

Abstract: Taking into account that the available capacities of human and material resources are key for a stable and sustainable health system of a country, this paper deals with the relation between the macroeconomic environment and the movement of the number of employees in the health system in the case of the Republic of Serbia. The aim of this paper is to make recommendations for further research based on the conducted analyses and to review the existing trends critically, in order to raise the level of public awareness in efforts to reduce the outflow of professional staff. The available official data of the institutions of the health system of the Republic of Serbia were used in the research, and time series from 2010 to 2018 were included.

Keywords: macroeconomic environment, capacities, healthcare personnel, regression analysis JEL classification: J45, I15, H55

Сажетак: Узимајући у обзир да су расположиви капацитети људских и материјалних ресурса кључни за стабилан и одржив здравствени систем земље, овај рад се бави односом макроекономског окружења и кретањем броја запослених у здравственом систему у случају Републике Србије. Циљ овог рада је давање препорука за даља истраживања на основу спроведених анализа, али и критички осврт на постојеће трендове, како би се подигао ниво свести јавности у напорима да се смањи одлив стручног особља. У истраживању су коришћени доступни званични подаци институција здравственог система Републике Србије, а обухваћене су и временске серије од 2010. до 2018. године.

Кључне речи: макроекономско окружење, капацитети, здравствена заштита, регресиона анализа JEЛ класификација: J45, I15, H55

\footnotetext{
Corresponding author
} 


\section{Introduction}

Since the official creation of the Republic of Serbia, significant changes have occurred in the number of healthcare employees, while the number of healthcare facilities is almost unchanged. An analysis of these trends from an economic point of view would be to find the cause and effect of such trends in economic growth in the previous period. For this reason, we suggest that presenting the results of this type of research is essential for sustainable healthcare system in the long-term period of time.

Table 1: Healthcare system facilities over years (2010-2018)

\begin{tabular}{|l|c|c|c|c|c|c|c|c|c|}
\hline \multicolumn{1}{|c|}{ Facilities } & 2010 & 2011 & 2012 & 2013 & 2014 & 2015 & 2016 & 2017 & 2018 \\
\hline Pharmacy & 35 & 35 & 35 & 35 & 35 & 35 & 35 & 35 & 35 \\
\hline Primary Healthcare Centres & 157 & 157 & 158 & 158 & 158 & 158 & 158 & 158 & 158 \\
\hline Institutes & 22 & 22 & 25 & 24 & 25 & 25 & 25 & 22 & 22 \\
\hline General Hospitals & 40 & 40 & 41 & 41 & 41 & 41 & 41 & 41 & 41 \\
\hline Special Hospitals & 37 & 37 & 36 & 36 & 36 & 36 & 36 & 34 & 34 \\
\hline Clinical Hospital Centres & 4 & 4 & 4 & 4 & 4 & 4 & 4 & 4 & 4 \\
\hline Clinical Centres & 4 & 4 & 4 & 4 & 4 & 4 & 4 & 4 & 4 \\
\hline Clinics & 6 & 6 & 7 & 7 & 7 & 7 & 7 & 7 & 7 \\
\hline Institutes & 16 & 16 & 16 & 16 & 16 & 16 & 16 & 16 & 16 \\
\hline Public Health Institutes & 23 & 23 & 25 & 25 & 25 & 25 & 25 & 25 & 25 \\
\hline $\begin{array}{l}\text { Military Healthcare } \\
\text { Institutions }\end{array}$ & 0 & 0 & 4 & 4 & 4 & 4 & 4 & 4 & 4 \\
\hline Total & 344 & 344 & 355 & 354 & 355 & 355 & 355 & 350 & 350 \\
\hline
\end{tabular}

Source: Institute of Public Health of Serbia 'Dr Milan Jovanović Batut'

As we can see in Table 1, the number of healthcare facilities has remained almost untouched in the last decade. The reason is that these objects were not demolished and rebuilt, but the essence is in the different way of registering them, and therefore keeping their records. For example, in 2012, there were structural changes to the Military Social Security Fund, and some of these facilities were registered both as state and military health care institutions.

Popović et al. (2015) found that healthcare jobs are performed by appropriate healthcare professionals. The main pillar around which a healthcare service is built is the profession of a Doctor, but the efficiency of the healthcare service and the results of the work of healthcare facilities depend on all healthcare staff. A team of healthcare professionals with diverse backgrounds, skills and experience is the most effective instrument in the healthcare of individuals and the general population.

Healthcare professionals represent the most important component in the healthcare system. Therefore, one of the most significant problems today is the use of health professionals to make healthcare as economical, accessible and effective as possible. Personnel policy and healthcare planning is designed to provide the right type of education to the right number and category of healthcare personnel (Timotić, 2004).

Stiglitz (2013) believes that in many small communities, there are not so many doctors left to choose from. Associating doctors with healthcare organizations can, in fact, significantly 
reduce competition in these areas. Moreover, competition among hospitals is also limited. In smaller environments, there are only a few. In an emergency, the individual is rarely able to make the choice, and even if given the opportunity, the choice is not really made by a patient but by the doctor.

Table 2: Trends of qualified healthcare employees (2010-2018)

\begin{tabular}{|l|r|r|r|r|r|r|r|r|r|}
\hline \multicolumn{1}{|c|}{ Category } & \multicolumn{1}{|c|}{2010} & \multicolumn{1}{c|}{2011} & \multicolumn{1}{c|}{2012} & \multicolumn{1}{c|}{2013} & \multicolumn{1}{c|}{2014} & \multicolumn{1}{c|}{2015} & \multicolumn{1}{c|}{2016} & \multicolumn{1}{c|}{2017} & 2018 \\
\hline Doctors & 21,054 & 21,030 & 20,960 & 21,098 & 20,645 & 20,450 & 20,054 & 20,008 & 19,984 \\
\hline Dentists & 2,242 & 2,227 & 2,160 & 2,099 & 2,005 & 1,901 & 1,688 & 1,634 & 1,607 \\
\hline $\begin{array}{l}\text { Pharmacist } \\
\text { s }\end{array}$ & 2,036 & 2,130 & 2,163 & 2,188 & 2,186 & 2,103 & 1,981 & 1,754 & 1,653 \\
\hline Other & 1,647 & 1,672 & 1,684 & 1,713 & 1,671 & 1,604 & 1,624 & 1,583 & 1,572 \\
\hline Nurses & 86,887 & 86,325 & 85,620 & 85,104 & 82,730 & 81,922 & 78,660 & 76,874 & 76,682 \\
\hline Summary & 113,866 & 113,384 & 112,587 & 112,202 & 109,237 & 107,980 & 104,007 & 101,853 & 101,498 \\
\hline
\end{tabular}

Source: Institute of Public Health of Serbia 'Dr Milan Jovanovic Batut'

Unlike facilities, the healthcare staff has undergone a dramatic change in both structural and quantitative terms. In the last ten years, virtually all categories in the healthcare system have experienced a decline in the number of employees, where the greatest difference is found among workers with secondary education (medical technicians - nurses). The number of this category was reduced by 10,000 workers compared to 2010, which is a huge problem in the quality of services provided. This problem is brought to light in regular daily life, and especially in situations of global health crises such as the current COVID-19 epidemic. The announcement of the pandemic of the new disease COVID-19 at the beginning of 2020 indicated the importance of the impact on economic events and trends, primarily through the possible occurrence of economic recession, which would be global and different from the previous ones due to the unusual factor that generates it (Praščević, 2020). Most of the missing personnel find their future in the countries of Western (Germany, Austria) and Northern Europe (Sweden, Norway), where drastically higher personal income is provided.

The aim of the paper is to give recommendations for further research based on the conducted analyses, but also to consider the existing trends critically, which would raise the level of public awareness in efforts to reduce the outflow of competent staff. The available official data from the institutions of the healthcare system of the Republic of Serbia were used in the research, and the time series from 2010 to 2018 were included.

\section{Literature preview}

The new approach to macroeconomic ambient, and it especially refers to macroeconomic fluctuations as well as political impact to macroeconomic performances, concerns the policymakers and their decisions, which sometimes create recessions rather than fixing them (Jakšić \& Praščević, 2011).

1 Associates with a university degree. 
Healthcare plays an important role in economic development because it may help to ensure a healthy and productive labour force for the economy (Gupta, 2002). In the early stage of economic development, labour and capital are the main contributors to the amount of health care services provided. Based on this concept, indicators such as ratios of doctors and number of hospital beds per 1000 population are still used to measure the development of health services (Nghiem \& Connelly, 2017).

Cerf (2018) suggests that governments worldwide should prioritize investment in healthcare system. The author states that increasing health investments boosts economic productivity. Likewise, respecting these principles make progress across all sustainable development goals.

Ercelik (2018) stated that, in the long-run, there is a positive relationship between GDP per capita, public and private spending for health and investment. Moreover, it is considered that investment and healthcare costs have significant impact on GDP. Accordingly, healthcare system's expenditure in Turkey, during the period of 1980 to 2015, affected GDP per capita in a positive way since the productivity of the country is improved.

On the other hand, depending on the specific objectives in the management and development of human resources, poor quality and inconsistency of data on human resources for healthcare system can give unrealistic, incomplete insight and represent a significant obstacle to the effective and economical planning and management of the entire human capital of the country (Šantrić-Milićević \& Simić, 2009). Budget deficits are increasingly noticeable in a number of countries, and Serbia has been struggling with it for years, with it becoming quite tense in the last year. Most countries, including Serbia, have shown a decreasing desire to invest in public hospitals and in healthcare system in general (Zekić \& Šegrt, 2015).

The function of financing the healthcare system has a decisive influence on the form of organization of the healthcare system, that is, more precisely, the way of payment of health insurance as one of the parts of the source of health system income. In Serbia, the health insurance system is based on compulsory health insurance, as well as in all European countries, and especially countries that had socialist social arrangements and voluntary health insurance (Damnjanović et al., 2018).

Ghana is pursuing activities to achieve sustainable development of the healthcare system by 2030 . In addition to the shortcomings of the empirical prognosis required by healthcare institutions to achieve these goals, labour shortages are also a major threat. For this reason, Asamani et al. (2018) modelled the required healthcare facilities in Ghana, and translated it into staffing needs year after year, based on established staffing standards, considering that only $68 \%$ of the needs for health care professionals are employed and available to provide medical services. The employment of unemployed and skilled health professionals is imperative.

Vladušić et al. (2020) studied the relationship between GDP and employment rates and examined their interdependence on the example of European Union countries. In this paper, they examined the correlation of GDP and employment as well as the statistical validity of the results. The results show positive trends in GDP growth and employment rates. A moderate positive correlation of the observed parameters was found, and the results are statistically significant. 
The World Health Organization forecasts an increase in the number of healthcare workers from 65 to 80 million workers by 2030. However, if we look at middle-income countries, including the Republic of Serbia, it should be noted that in the coming period, this group of countries will face a shortage of healthcare workers, given that demand for them will soon exceed supply (Liu, 2016). This means that even if these countries are able to produce additional workers to meet the need threshold, they may not be able to employ and retain these workers without considerably higher economic growth, especially in the health sector (Scheffler et al., 2018).

\section{Methodology}

For the purposes of this research, the method of linear regression was used, which was used to model the variables in relation to the data used in the research. In this model, only one variable is presented as explanatory, while all others are dependent. On the example of the Republic of Serbia, in the period from 2010 to 2018, trends in the number of qualified health workers and trends in some of the macroeconomic parameters were observed.

Table 3: Research data

\begin{tabular}{|c|c|c|c|c|c|c|}
\hline Yr & $\begin{array}{c}\text { Real GDP } \\
\text { growth (\%) }\end{array}$ & $\begin{array}{c}\text { GDP } \\
(\text { mil. } €)\end{array}$ & $\begin{array}{c}\text { Unemploymen } \\
\text { t rate (\%) }\end{array}$ & $\begin{array}{c}\text { Average } \\
\text { Personal } \\
\text { Income }(€)\end{array}$ & $\begin{array}{c}\text { Public } \\
\text { Debt } \\
(\% \text { of } \\
\text { GDP) }\end{array}$ & $\begin{array}{c}\text { Healthcare } \\
\text { qualified } \\
\text { workers }\end{array}$ \\
\hline 2010 & 0.7 & 31,546 & 19.2 & 331.8 & 39.5 & 113,866 \\
\hline 2011 & 2.0 & 35,432 & 23.0 & 372.5 & 42.8 & 113,384 \\
\hline 2012 & -0.7 & 33,679 & 23.9 & 366.1 & 52.9 & 112,587 \\
\hline 2013 & 2.9 & 36,427 & 22.1 & 388.5 & 56.0 & 112,202 \\
\hline 2014 & -1.6 & 35,467 & 19.2 & 379.8 & 66.2 & 109,237 \\
\hline 2015 & 1.8 & 35,716 & 17.7 & 367.9 & 70.0 & 107,980 \\
\hline 2016 & 3.3 & 36,723 & 15.3 & 374.5 & 67.8 & 104,007 \\
\hline 2017 & 2.0 & 39,183 & 13.5 & 383.9 & 57.9 & 101,853 \\
\hline 2018 & 4.4 & 42,855 & 12.7 & 419.7 & 53.7 & 101,498 \\
\hline
\end{tabular}

Source: National Bank of Serbia; Institute of Public Health of Serbia

The most common method of linear regression, which will be applied here as well, is the least squares method. By applying this method, the line of the observed data is adjusted to the sum of the squares of the calculated vertical deviation, thus removing the negative values. When the result is obtained in the calculation of the regression line within the observed data, the value that has the largest lag compared to the others is taken as an external point. However, such results may be a consequence of incorrectly entered data, as well as a cause of unfavorable regression line fitting. On the other hand, if a form of horizontal deviation appears, the reason is the influence of the recorded value on the slope of the regression line.

The linear regression method is based on the principle that the deviation of points from the regression line is represented as the smallest sum of squares (Todić, 1973). This relationship can be presented as 


$$
f(a, b)=\Sigma\left(y-a-b x_{i}\right)^{2}=\min
$$

what follows is

$$
\begin{aligned}
& \frac{\delta f(a b)}{\delta a}=-2 \Sigma\left(y-a-b x_{i}\right)=0 \\
& \frac{\delta f(a b)}{\delta b}=-2 \Sigma\left(y_{i}-a-b x_{i}\right) X_{i}=0
\end{aligned}
$$

$$
\begin{aligned}
& \text { or } \\
& \Sigma y_{i}=N a+b \Sigma x_{i} \\
& \Sigma x_{i} y_{i}=a \Sigma x_{i}+b \Sigma x_{i}
\end{aligned}
$$

The method for calculating the unknown indicators is shown as follows

$$
\bar{a}=\bar{y}-b \bar{x}
$$

$$
b=\frac{\sum x_{i} y_{i}-\bar{y} \Sigma x_{i}}{\Sigma x_{i}{ }^{2}-\bar{x} \Sigma x_{i}}
$$

Provided that the center of the coordinate system is actually the center of the observed phenomenon, then the following applies

$$
b=\frac{\Sigma\left(x_{i}-\bar{x}\right) y_{i}}{\Sigma\left(x_{i}-\bar{X}\right)^{2}}
$$

on the basis of which the final form of the equation is reached

$$
\bar{y}_{i}=a+b x_{i}
$$


Representation of the residual residue on the $\mathrm{Y}$ axis and its consideration in relation to the reference value on the $\mathrm{X}$ axis can help to detect the possible occurrence of any form of nonlinear relationship. The data used in this research are official data of the National Bank of Serbia as well as the Institute of Public Health of Serbia "Dr Milan Jovanović Batut".

\section{Results and discussion}

The verification of the normality of the data was performed using the Shapiro-Wilk test, providing conditions for the realization of further research, i.e. providing conditions for a valid interpretation of the data. As all data values are significantly above the significance threshold, the assumption was adopted that the normality of the data is adequate.

Table 4: Shapiro-Wilk test

\begin{tabular}{|l|c|c|}
\hline \multicolumn{1}{|c|}{ Variables } & Shapiro-Wilk Coefficient & p-value \\
\hline Real GDP growth & 0.95944 & 0.79239 \\
\hline GDP & 0.93386 & 0.51896 \\
\hline Unemployment rate & 0.93801 & 0.56112 \\
\hline Average Personal Income & 0.92477 & 0.43322 \\
\hline Public Debt qualified & 0.93712 & 0.55190 \\
\hline $\begin{array}{l}\text { Healthcare } \\
\text { workers }\end{array}$ & 0.87283 & 0.13182 \\
\hline
\end{tabular}

Source: the authors' own research

Analysis of wastefulness of the so-called Scatterplot can be a useful tool in determining the strength of relationships between variables. If there appears to be no correlation between the proposed explanatory and dependent variables (i.e., the scattering does not show any upward or downward trends), fitting a linear regression model to the data is unlikely to provide a useful model. A very important piece of information, which we obtain within the test by means of linear regression methods, is the strength of the correlation of the examined data, expressed within the correlation coefficient, the value of which ranges from -1 to 1 .

If we take that $Y=a+b X$ is the basic form of the regression equation, then we should define that $X$ is the number of healthcare workers in a given year, thus representing an explanatory variable, while $Y$ represents the values of macroeconomic parameters in this case, i.e. the dependent variable. If we want to represent a regression line graphically, then it should be noted that $b$ is an indicator of the slope of that line and that $a$ is the value of the cross-section when $X$ is equal to 0 .

Table 5: Research results

\begin{tabular}{|l|c|c|c|c|c|c|}
\hline & $\mathrm{r}$ & $\mathrm{r}^{2}$ & $\begin{array}{c}\text { Adj. } \\
\mathrm{r}^{2}\end{array}$ & $\begin{array}{c}\text { Std. Err. } \\
\text { of Est. }\end{array}$ & t Stat & P-value \\
\hline Real GDP growth & 0.839 & 0.705 & 0.663 & 0.132 & -4.091 & 0.004 \\
\hline
\end{tabular}




\begin{tabular}{|l|l|l|l|l|l|l|}
\hline GDP & 0.928 & 0.861 & 0.841 & 0.000 & 6.604 & 0.000 \\
\hline Unemployment rate & 0.646 & 0.417 & 0.334 & 0.001 & -2.239 & 0.060 \\
\hline Average Personal Income & 0.509 & 0.259 & 0.153 & 0.000 & -1.565 & 0.161 \\
\hline Public Debt & 0.839 & 0.705 & 0.663 & 0.132 & -4.091 & 0.004 \\
\hline
\end{tabular}

Source: Research of the authors

$\mathrm{r}$ - linear regression coefficient (estimated coefficient)

$\mathrm{r}^{2}$ - determination coefficient

Adj. $\mathrm{r}^{2}-$ less biased determination coefficient

Std. Err. of Est. - standard error of model estimation

P-value - testing the null hypothesis

t Stat - null hypothesis significance for predictor variable

Based on the Chaddock scale (Bacho et al., 2019; Telizhenko et al., 2019), an estimate of the linear correlation coefficient between variables in a specific case was performed. Thus, a noticeable positive correlation was established between the movement of the number of qualified health workers and real GDP growth, i.e. average personal income and public debt $[0.5<\mathrm{r}<0.7]$. In the next interval from 0.7 to 0.9 , there is an indicator of the value of GDP and its relation to the explanatory variable. Finally, the strongest form of positive correlation (0.928) was observed in relation to the movement of the number of health workers and the unemployment rate in the observed period. It means that the mentioned decline in number of healthcare personnel leads to reduced unemployment rate, considering explained phenomenon called 'brain drain'.

The $\mathrm{r}^{2}$ points out that as much as $86.1 \%$ of the value of the unemployment rate is caused by the number of qualified healthcare workers, while the remaining $13.9 \%$ is a consequence of other indicators. Moreover, it should be noted that only GDP impacts the number of qualified healthcare workers significantly (70.5\%), while in other observed parameters this value is negligible.

Within the adjusted $\mathrm{r}^{2}$ coefficient, only the unemployment rate is presented as a parameter that will not increase with the growth of the number of explanatory variables. Therefore, it is only statistically significant, judging by the obtained value $(0.841)$, unlike other parameters, which have no statistical significance. This is supported by the highest value of the determined standardized error in the case of GDP (0.132), at the same time as a negligible value of statistical significance. The same can be determined by observing the $t$ values obtained in the research. There is a positive impact on all dependent variables, but only the values of GDP and unemployment rate are statistically significant, and for this reason, only these two parameters are taken into consideration.

$\mathrm{P}$-value is the value for each term tests the null hypothesis that the coefficient is equal to zero, which means that there is no effect of explanatory to the dependent variable. If the p-value is above 0.05 the null could be accepted, while statistically significant regressors are confirmed in the case when $\mathrm{p}<0.05$. Accordingly, the null hypothesis can be rejected when it comes to GDP and the unemployment rate. 


\section{Conclusion}

Regarding the results of previous researches, on a similar topic, the significance of the interdependence of the number of healthcare personnel and macroeconomic indicators have been proven, on the example of the Republic of Serbia. A strong correlation was established between the values of the unemployment rate coefficient and GDP in relation to the number of healthcare workers in the period from 2010 to 2018.

The obtained results create the conditions for us to draw a conclusion about the mutual influence of the number of healthcare workers and certain macroeconomic parameters, in the case of the Republic of Serbia. They tell us that the macroeconomic environment that has been created and shaped in the past decade greatly influences the movement of the number of healthcare workers in the healthcare system of the Republic of Serbia. On the other hand, a strong and stable healthcare system with minimal fluctuations in the number of employees is one in a series of preconditions for creating a favorable and efficient national economy of a country. These results should encourage macroeconomic policy makers to prevent 'brain drain' that is, a continuing deficit in the number of workers in the healthcare system.

As the authors of this paper, we propose that future research on this topic be directed towards examining the impact of the efficiency of certain categories of healthcare workers on sustainable economic development, after which the examined results of specific samples would be compared with the same indicators of developed and developing countries. Taking into consideration numerous examples of overstrain and difficulties in the functioning of healthcare systems, including the Republic of Serbia, during the current COVID-19 pandemic, their problem should be concretized, and guidelines for planning and stabilization of a country's healthcare system, supporting civil society even in unforeseen situations.

\section{References}

Asamani, J.A. Chebere, M.M., Barton, P.M., D’Almeida, S.A., Odame, E.A. \& Oppong, R. (2018). Forecast of healthcare facilities and health and health workforce requirements for the public sector in Ghana, 2016-2026. International Journal of Health Policy and Management, 7(11), 1040-1052. Doi: https://doi.org/10.15171/ijhpm.2018.64

Bacho, R., Pukala, R., Hlibko, S., Vnukova, N. \& Pola, P. (2019). Information management: the key driver of the economic system's development. Marketing and Management Innovations, 3, 297-307. Doi: https://doi.org/10.21272/mmi.2019.3-23

Cerf, M. (2018). The sustainable development goals: contextualizing Africa's economic and health landscape. Global Challenges, 2(8). Doi: https://doi.org/10.1002/gch2.201800014 
Damnjanović, R., Vladisavljević, V. \& Arapović, T. (2018). Modeli finansiranja zdravstvenog osiguranja. Oditor - časopis za menadžment, finansije i pravo, 4(1), 85-93, Doi: https://doi.org/10.5937/Oditor1801085D

Ercelik, G. (2018). The relationship between health expenditure and economic growth in Turkey from 1980 to 2015. Journal of Politics and Management, 1(1), 1-8.

Gupta, S., Verhoeven, M. \& Tiongson, E. R. (2002). The effectiveness of government spending on education and health care in developing and transition economies. European Journal of Political Economy, 18(4), 717-737. Doi: https://doi.org/10.1016/S01762680(02)00116-7

Institut za javno zdravlje Srbije 'dr Milan Jovanović Batut' .(2020) Izveštaji i analize, Retrieved October, 25, from http://www.batut.org.rs/index.php?category id $=66$

Jakšić, M. \& Praščević, A. (2011). The new political macroeconomics in modern macroeconomics and its appliance to transition processes in Serbia. Panoeconomics, 4, 545-557. Doi: https://doi.org/10.2298/PAN1104545J

Liu, J. X., Goryakin, Y., Maeda, A., Bruckner, T., \& Scheffler, R. (2016). Global health workforce labor market projections for 2030. The World Bank. Doi: https://doi.org/10.1596/1813-9450-7790

Narodna banka Srbije (2019), Makroekonomski indikatori. Retrieved October, 20, from https://www.nbs.rs/internet/latinica/18/18 3/podaci.html

Nghiem, S. H., \& Connelly, L. B. (2017). Convergence and determinants of health expenditures in OECD countries. Health Economics Review,7(1), 1-11. Doi: https://doi.org/10.1186/s13561-017-0164-4

Popović, R., Obradović, M., Mitrović, B. \& Timotić, B. (2015). Kretanje ukupno zaposlenih radnika u zdravstvenim ustanovama Srbije u drugoj polovini XX veka. Zdravstvena zaštita, 44(4), 32-36.

Praščević, A. (2020). Ekonomski šok pandemije COVID 19 - prekretnica u globalnim ekonomskim kretanjima. Ekonomske ideje i praksa, 37, 7-23.

Šantrić-Milićević, M. \& Simić, S. (2009). Zdravstveni kadar u Srbiji u period pre i posle 1950. godine. Medicinski pregled, 62(7-8), 379-383.

Scheffler, R. M., Campbell, J., Cometto, G., Maeda, A., Liu, J., Bruckner, T. A., Arnold, D.R. \& Evans, T. (2018). Forecasting imbalances in the global health labor market and devising policy responses.Human resources for health, 16(1), Doi: https://doi.org/10.1186/s12960-017-0264-6

Stiglitz, J. (2013). Ekonomija javnog sektora. Beograd: Ekonomski fakultet

Telizhenko, O., Pavlenko, O., Martynets, V. \& Rybalchenko, S. (2019). Modeling the Influence of cluster components on the economic development of a territory. TEM Journal, 8(3), 900-907. Doi: https://doi.org/10.18421/TEM83-30 
Timotić, B. (2004). Uvod u medicinu. Beograd: Elit medica

Todić, R. (1973). Osnovi statističke analize. Beograd: Savremena administracija

Vladušić, Lj., Živković, A. \& Pantić, N. (2020). Macroeconomic Analysis of GDP and Employment in EU Countries. Ekonomika, 66(1), 65-76. Doi: https://doi.org/10.5937/ekonomika2001065V

Zekić, M. \& Šegrt, S. (2015). Uticaj privatnog zdravstvenog osiguranja na makroekonomski ambijent Republike Srbije. Oditor - časopis za menadžment, finansije $i$ pravo, 10, 4-9. Doi: https://doi.org/10.5937/Oditor1510004Z 
